\title{
ENVIRONMENTAL PROTECTION IN ARMED CONFLICT ACCORDING TO INTERNATIONAL HUMANITARIAN LAW
}

\author{
Desy Churul Aini ${ }^{1}$, Desia Rakhma Banjarani ${ }^{2}$ \\ ${ }^{1}$ Faculty Of Law Lampung University \\ JL. Sumantri Brojonegoro No.1, Kota Bandar Lampung, Lampung, 35145, Indonesia \\ Telp./Fax: +62-721-701609 Email: desychurulaini@yahoo.com \\ ${ }^{2}$ Faculty Of Law Lampung University \\ JL. Sumantri Brojonegoro No.1, Kota Bandar Lampung, Lampung, 35145, Indonesia \\ Telp./Fax: +62-721-701609 Email: desiarahma7@gmail.com \\ Submitted: Jan 14, 2018; Reviewed: Jun 13, 2018; Accepted: Jun 28, 2018
}

\begin{abstract}
The environment is a victim of various armed conflicts that occur in some parts of the world. Such as Congo war in 1998 that create environmental damage like deployment of the HIV-AIDS virus, the extinction of national parks, wildlife poaching and the forest burning. In addition the Rwanda civil war in 1994 affected the loss of biodiversity, natural resources and population decline in rare animals such as the African Gorillas. While the former Yugoslavia war in 1991 that impact in environmental pollution of water, air and land that threaten human survival.

The environment becomes a victim when the war was happend its caused the human, but on the other side, the environment can't be separated from human life because somehow humans need the environment to. However, when the war was happend human can't maintaining the environment even though there have been rules that regulate about the protection of the environment when the war takes place. Therefore, its necessary to analysed an environmental protection in armed conflict according to international humanitarian law.

This research is discusses about how an environmental protection in armed conflict according to international humanitarian law, which aims to explain the regulations that apply to protect the environment at the armed conflict. This research uses normative law approach (literature research).

The results of this study show that environmental protection in armed conflict is regulated in the conventions of international humanitarian law both from the Hague Law and the Geneva Law. In The Hague law the environmental protection is governed by the IV Hague Convention 1907of respecting the laws and customs of war and land Art 23 $(g)$ and Art 55. In the Geneva Law an environmental protection is contained in the IV Geneva Convention 1949 Art 53 and Additional Protocol I in 1977 Art 35 (3), 54, 55, 56, 59, and Art 68. Basically both of Geneva and Hague Law against the use of weapons during the war that have an effected in environmental damage and the existence of precautions in the war on environmental protection life. Beside the Geneva and the Hague Law there are have other arrangements to protect the environment in the event of a war that is in ENMOD Convention Art 1 and 2.
\end{abstract}

Keywords: Environment, Geneva Law, Hague Law, War 


\section{INTRODUCTION}

Human activity in this world was grew progressively every time, the development followed by the development of technology. The activity is also done in the environment, ${ }^{1}$ from that has many benefits or results derived from the environment itself. The result of the environment is used by humans to fulfill their needs, as a result of wanting to get their needs then human also extends its power with war. ${ }^{2}$ The war that created of many damage, especially for humans and also damage to the environment. ${ }^{3}$ For that we need a protection from every international community to prevent the destruction of the environment. It is necessary for the participation of international institutions, especially from the United Nations, to protect the environment from the destruction caused by the war. ${ }^{4}$

\footnotetext{
${ }^{1}$ According to Otto Soemarwato, The environment is a space occupied by living things with other non-living objects, living beings are not independent, but interact with the environment, in which there is a reciprocal relationship between living beings with the environment. Hyronimus Rhiti, Kompleksitas Permasalahan Lingkungan Hidup, , Yogyakarta: Andy Offset, 2006, hlm.7.

${ }^{2}$ Broto Wardoyo, Perkembangan, Paradigma, dan Konsep Keamanan Internasional \& Relevansinya untuk Indonesia, Klaten: Nugra Media, p. 24

${ }^{3}$ Adnan Buyung Nasution, Instrumen Pokok Hak Asasi Manusia, Jakarta: Yayasan Obor Indonesia, 2006, p. 241

${ }^{4}$ Arthur $\mathrm{H}$ Westing, Cultural Norm, War and the Environment, New York: Oxford University Press, 1988 , p. 19
}

Armed conflicts or wars ${ }^{5}$ are often supported by mass destructive armaments which is result in many casualties and property. ${ }^{6}$ The use of weapons that can effect to big damage such as chemical and nuclear weapons its began to be used by advanced countries for weapon systems. ${ }^{7}$ That wars was happened about 50 years period, mankind experienced of an armed conflict in worries number. ${ }^{8}$ These armed conflicts occur on almost every continent. During that time, instruments for the protection of war victims continued to grow. ${ }^{9}$ The death victim and the destruction of the city became the public's attention as a result of war, but one of the main victims of war and armed conflict is the environment.

As happened in the Congo war Since August 1998 civil wars occurred in

\footnotetext{
${ }^{5} \mathrm{War}$ is a dispute, that is by using violence that often takes the form of an armed force, nevertheless war should not conflict with international law, but rather a state governed by international law. Djatikoesoemo, Hukum Internasional Bagian Perang, N.V. Jakarta:Pemandangan Djakarta, 1956, hlm. 2.

${ }^{6}$ Harry Purwanto, "Hukum Humaniter Internasional dan Hukum Hak Asasi Manusia", Jurnal Mimbar Hukum, Vol. 18, No.2, 2006, p. 1

${ }^{7}$ Paul Rurherford, Weapons of Mass Persuasion, Toronto: University of Toronto Press, hlm. 27

${ }^{8}$ Jean-Marie Henckaerts, Studi (kajian) tentang Hukum Humaniter Internasional Kebiasaan: Sebuah sumbangan bagi pemahaman dan penghormatan terhadap tertib hukum dalam konflik bersenjata, Jakarta, Volume 87, 2005, p. 1 ${ }^{9}$ Ibid
} 
the region which resulted in many deaths but the environment became a victim concern. ${ }^{10}$ Only $45 \%$ of people have access to safe drinking water. In addition, another victim of war is environmental issues, such as endangered national parks due to frequent exploitation of their mineral content. Refugees are hunting wildlife for consumption or selling. The population of elephants in Africa has declined as a result of ivory hunting. Farmers burn some of the forest for use as agricultural land. ${ }^{11}$

Besides the Congos war, the civil war that occurred in Rwanda in 1994 also had an adverse impact on the environment. After killing 800.000 people, environmental impacts from the war such as the increased of illegal logging for housing development, and clearance of forested areas for agricultural purposes. ${ }^{12}$ Illegal logging extensive has resulted in the damage of biodiversity and other natural resources such as rare plants and animals like the African Gorillas in Rwanda thas

\footnotetext{
${ }^{10} \mathrm{http}: / / \mathrm{www} . \mathrm{globalissues.org/article/87/the-}$ democratic-republic-of-congo, accesed on 10 Oktober 2016, at 17:31 WIB

${ }^{11} \mathrm{http}: / / \mathrm{www}$. lenntech.com/environmental-

effects-war.htm, accesed on 10 Oktober 2016 , at 17:35 WIB

${ }^{12} \mathrm{http} / / / \mathrm{www}$.accord.org.za/ajcrissues $/ \% \mathrm{EF} \% \mathrm{BF} \% \mathrm{BCenvironmental-causes-}$ and-impacts-of-the-genocide-in-rwanda/, accesed on 10 Oktober 2016, at 17:42 WIB
}

have drop drastic number. ${ }^{13}$ Another civil war also occurred in the former Yugoslavia countries in 1991, whereas the war claimed the lives about 100.000 people and more than two million people displaced. ${ }^{14}$ Yugoslavian warfare also has an impact on the environment such as the environmental pollution of water, air and land that threaten the survival of human life. $^{15}$

A few wars are mentioned just little sample of the worst environmental impacts of war. In every war, environmental problems that often occur are polluted water, burnt agricultural, illegal logging, contaminated lands and animals are killed. ${ }^{16}$ The environment becomes a victim caused war, but on the other side the environment can not be separated from human life. ${ }^{17}$ Due to environmental problems caused by this war is so complex and become one of the problems is quite heavy then it is regu-

\footnotetext{
${ }^{13} \mathrm{http}: / / \mathrm{www}$. lenntech.com/environmentaleffects-war.htm, accesed on 10 Oktober 2016, at 17:35 WIB

${ }^{14} \mathrm{http}: / /$ endgenocide.org/learn/pastgenocides/the-bosnian-war-and-srebrenicagenocide/, accessed on 23 November 2016, at 19:19 WIB

${ }^{15} \mathrm{http}: / / \mathrm{www}$. assembly.coe.int/nw/xml/XRef/X 2H-XrefViewHTML.asp?FileID=9143\&lang=EN, accessed on 17 Agustus 2017, at 13:34 WIB ${ }^{16}$ http://indonesian.irib.ir/ranah/kultur/item/102 680-antisipasi-perusakan-lingkungan-hidupakibat-perang, accessed on 10 Oktober 2016, at14:04

${ }^{17}$ http://www.berpendidikan.com/2015/06/artipenting-lingkungan-hidup-bagi.html, accessed on 10 Oktober 2016, at14:18
} 
lated in International Humanitarian Law. ${ }^{18}$ International Humanitarian Law regulates the environmental protection of war or armed conflict contained in its legal sources which are included in the source of international law. ${ }^{19}$

Based on the above background, the issue will be addressed in this study is how is environmental protection in armed conflict according to international humanitarian law? The method used is a normative legal research method and data were obtained on secondary data derived from literature sources such as literature, articles and Internet sites.

\section{DISCUSSION}

\section{Environmental Protection in The Hague Law}

The environmental protection of armed conflict is mentioned in the international humanitarian law. Geza Herzegh provides the formulation of humanitarian law that is part of the rules of public international law that serves as the protection of individuals in times of armed conflict. Ac-

\footnotetext{
18 According by Mochtar Kusumaatmadja, International Humanitarian Law is part of the law governing the provisions of the protection of victims of war, while the laws of war govern the war itself and concerning the way of war itself. Arlina Permanasari, Pengantar Hukum Humaniter, Jakarta: Miamita Print, 1999, p. 9.

${ }^{19}$ The sources of international law consist of international treaties, general law principles, international customs, court decisions and doctrines. Article 38 of the Statute of the International Court of Justice
}

cording to Geza the place of humanitarian law is in addition to the norms of war it is closely related to them, but it must be clearly distinguish from these different goals and spirits. ${ }^{20}$ The same thing also explained by Mochtar Kusumaatmadja that humanitarian law is part of the law that regulates provisions of protection of war victims, different from the laws of war that govern the war itself and everything that is about the way of doing war. ${ }^{21}$ The purpose of humanitarian law is to provide protection to those who suffer or fall victim to war, whether real and active in combat, or those who do not participate in the dispute (civilians). ${ }^{22}$ Humanitarian law applies only when an armed conflict happened and to identify the enforcement of humanitarian law it must be distinguished between international armed conflict and non-international armed conflict. $^{23}$

International humanitarian law formerly known as war law or armed rule law is one chapter of the public international law. This law has the same old historical age with human civilization. ${ }^{24}$ In-

\footnotetext{
${ }^{20}$ Arlina Permanasari, Op Cit., p.9

${ }^{21}$ Ibid.

22 Haryomataram, Pengantar Hukum Humaniter, Jakarta: Raja Grafindo, 2005, hlm 3.

${ }^{23}$ Roberta Arnold, International Humanitarian Law dan Human Rights Law, Boston: Martinus Nijhoff Publisher, 2008, p.357.

${ }^{24}$ Arlina Permanasari, Op Cit., p.1
} 
ternational humanitarian law not only regulates about the war procedures that contained in the hague law, ${ }^{25}$ but also provides protection against victims of the war that contained in the geneva law. ${ }^{26}$ The hague law include the 1899 hague convention (consisting of 3 covention and 3 declarations) and the hague 1907 convention (consisting of 13 conventions). ${ }^{27}$ Whereas the geneva law includes a convention of jenewa that protects the victims of war. ${ }^{28}$ In hague law and geneva law both govern the protection of the environment in the war.

Environmental protection in the hague law is contained in the convention on the prohibition of the use of toxic or toxic weapons and in exploring the natural resources of the opposing country such as forests, this is described and detailed in

\footnotetext{
${ }^{25}$ The Hague Laws are a source of written humanitarian law that has a regulatory focus on the manner of warfare and the kind of weapons that are allowed to be used during wartime. The laws of The Hague are more related to the rules of the way and means of fighting and focusing on military operations. C. De Rover, To Serve and To Protect Acuan Universal Penegakan HAM, jakarta: Raja Grafindo Persada, 2000, p. 100.

${ }^{26}$ The law of Geneva or in english is called The Geneva Laws which is the law that regulates the protection of combatants and civilians from war. Generally speaking the law of Geneva refers to a group of norms of International $\mathrm{Hu}$ manitarian Law that focuses more on the conditions of war victims. Harry Purwanto, Op.Cit., p. 189

${ }^{27}$ Haryomataram, Op Cit., p. 46.

${ }^{28}$ C. De Rover, Op.Cit. p. 101
}

the 4th hague annex and convention. ${ }^{29}$ In addition, the hague convention also uses the international customary principle of environmental protection, including basic principles of need, proportionality, and discrimination between military and civilian targets. ${ }^{30}$ In article 23 (g) environmental protection in the 4th hague convention of convention IV respecting the laws and customs of war and land that said,

"it is especially forbidden to destroy or confiscate the property of the enemy, unless such destruction or seizure shall be prosecuted by need of war .... ".

The purpose of this article is the prohibition of destruction of civilian objects in wars that affect the environment. ${ }^{31}$ But the limit of this article is that while protecting the property from destruction, the military needs are still defended and recognized in this article. ${ }^{32}$

\section{Environmental Protection in the Gene- va Law}

Another source of humanitarian law that regulates about environmental protection at war is contained in the geneva law.

\footnotetext{
${ }^{29}$ Art 23 (a) Convention IV respecting the laws and customs of war and land

${ }^{30}$ Alexander Kiss and Dinah Ashelton, Guide to International Protection Law, Boston: Library of Congress Cataloging-in-Publication Data, 2007, p. 255

${ }^{31} \mathrm{http}$ ///www.worldlii.org/int/journals/ISILYBI HRL/2001/13.html, accessed on 10 Oktober 2016, at 20:39 WIB

${ }^{32}$ Peter Richard \& Michael N.Schmitt, “ Mars Meets Mother Nature: Protecting the Environment During Armed Conflict”, Stetson Law Review, vol.28, 1999, p.1047-1068.
} 
Generally the geneva law refers to a group of norms international humanitarian law that focuses more on the conditions of war victims. The development of the geneva law can not be separated from the presence of the International Committee of the Red Cross and also Henry Dunant, the founding character of the $\mathrm{ICRC}^{33}$ and the action of the Red Cross. ${ }^{34}$ Henry Dunant is known as the founder of the International Committee of the Red Cross (ICRC). War in Solferino Northern Italy in 1859 is the background of Henry to built ICRC. ${ }^{35}$ In the geneva law consists of fourth conventions: ${ }^{36}$

\footnotetext{
33 The ICRC (International Committee of the Red Cross) or international red cross committee is the largest humanitarian network in the world. Its mission is to alleviate human suffering, protect life and health, and uphold human dignity especially during armed conflicts and other emergencies. The International Red Cross is present in every country and supported by millions of volunteers. The International Red Cross is dedicated to preventing and reducing human suffering in wars and in emergencies such as epidemics, floods and earthquakes, https://www.icrc.org/en/movement, accessed on 22 September 2016, at 20:12

${ }^{34}$ Arie Siswanto, Hukum Pidana Internasional, Yogyakarta: Andi, 2015, p. 156

35 The Selferino War was a war involving the Austrian kingdom against the French-Sardinian coalition. On June 24, 1859, the alliance of France and Sardinia under Napoleon III met Austrian troops in the small village of Solferino in northern Italy. The war involving nearly 300.000 personnel took place with great force, estimated there are about 4500 people who died and tens of thousands more injured. Http://www.redcross.org.uk/About-us/Whowe-are/Museum-and-archives/Historicalfactsheets/The-Battle-of-Solferino, accessed on September 26, 2016, at 19:59 WIB

${ }^{36}$ Haryomataram, Loc. Cit.
}

1. The first geneva convention "for the Amelioration of the Condition of the Wounded and Sick in Armed Forces in the Field"

2. The second geneva convention "for the Amelioration of the Condition of Wounded, Sick and Shipwrecked Members of Armed Forces at Sea"

3. The third geneva convention "relative to the Treatment of Prisoners of War"

4. The fourth geneva convention "relative to the Protection of Civilian Persons in Time of War".

From all of Geneva Conventions 1949 only two convention that contain about regulation of environmental safeguards even with exclusive agreements and the context of military occupation. ${ }^{37}$ Article 53 of the Geneva Convention IV 1949 further extends the protection of property that previous article is contained in Hague Convention article 55, which said that: ${ }^{38}$ Any destruction by the occupying power of individual property or personal property of an individual or collective for an individual, or for a state, or other public authority, or to any social or cooperative organization, is prohibited,

\footnotetext{
${ }^{37} \mathrm{http}: / /$ www.worldlii.org/int/journals/ISILYBI HRL/2001/13.html, accessed on 10 Oktober 2016, at 20:39 WIB

${ }^{38}$ Article 53 Geneva Convention IV 1949
} 
unless such damage is provided absolutely necessary by military operations.

Beside the four conventions that mentioned above, the geneva law also has several additional protocols. The existence of these additional protocols is intended to improve the performance of the four conventions geneva law, without relieve the principles that contained in the Geneva Conventions 1949. ${ }^{39}$ This additional protocol was drafted in 1977 and divided into two books: ${ }^{40}$

1. Protocol I, contains several rules about war or armed conflicts that are cross country (international).

2. Protocol II, contains some rules concerning war or armed conflict that occurred in the territory of one of the participants state between their arm and the rebels in their territory area. In other words, this additional protocol is regulate armed conflic noninternational. This Additional Protocol II adds to the content / scope of Article 3 of the Geneva Conventions.

Although the character of additional protocol is complementary of Geneva Conventions 1949, but protocol I and II have a large explanation about the protection of war victims and enhance of legal protection for injured and dead civilians, and this additional protocol is the first detail international treaty to regulate human-

\footnotetext{
${ }^{39}$ Haryomataram, Op.Cit., p.49

${ }^{40}$ Ibid.
}

ity in in civil war. ${ }^{41}$ Both Protocol I and Protocol II have been ratified by 160 countries to make complete and universal humanitarian law and to better adapt to the occurrence of modern conflicts. ${ }^{42}$ However, in the case of environmental protection in armed conflict only Additional Protocol I that regulates it, and Additional Protocol II doesn't regulate it.

The regulation of environmental protection during the war was contained in Article 35 paragraph (3) of Additional Protocol I of 1977 which govern as follows: ${ }^{43}$

"It is prohibited to employ methods or means of warfare which are intended, or may be expected, to cause widespread, long-term and severe damage to the natural environment".

Then in article 55 Additional Protocol I 1977 regulate that: ${ }^{44}$

"1. Care shall be taken in warfare to protect the natural environment against widespread, long-term and severe damage. This protection includes a prohibition of the use of methods or means of werfare which are intended or may be expected to cause such damage to the natural environment and thereby to prejudice the health or survival of the population.

2. Attack against the natural environment by way of reprisals are prohibited."

\footnotetext{
${ }^{41}$ https://www.icrc.org/eng/resources/document s/misc/additional-protocols-1977.htm, accessed on 10 September 2016, at 20:11 WIB

${ }^{42}$ Ibid.

${ }^{43}$ Article 35 (3) Additional Protocol I 1977

${ }^{44}$ Article 55 Additional Protocol I 1977
} 
In Additional Protocol I 1977 Article 35 paragraph (3) regulates the prohibition of the use of weapons that has an effect for environmental damage. While in Article 55 of Additional Protocol I of 1977 is directed against prudential warning actions concerning the protection of the environment for the survival of mankind during armed conflict. Article 35 contains the term "widespread and severe long term" but it has not been determined how long the long-term provisions are at the time of the drafting of the Protocol. ${ }^{45}$ Basically in Additional Protocol I there is a section that explains the basic provisions of ways and device to use of warfare so isn't has impact for environmental damage, that is: ${ }^{46}$

1. In any armed conflict, the right of the state parties in armed conflict to choose the methods and device of warfare is not unlimited.

2. It is prohibited to use weapons, projektiles, materials and methods in the warfare that result in excessive injury or unnecessary suffering.

3. It is prohibited to use methods and device of warfare aimed at or petentially has effectt in extensive, widespread and long-term damage to the natural environment of the state.

\footnotetext{
${ }^{45}$ F.Kalshoven, Reaffirmation and Development of International Humanitarian Law Applicable in Armed Conflicts : The Diplomatic Conference", Geneva, 1974-1977 (PartII), Netherlands Yearbook of International Law, vol. 9,1978, p.130.

${ }^{46}$ Section 3 Additional Protocol I
}

About the manner of war, the provisions of section 3 of Additional Protocol I are addition and refinement of what is contained in the Hague Convention of 1907. ${ }^{47}$ However, has doubts in Article 36 of Section 3 of Additional Protocol I that describes of the using new weapons, which in the use of new weapons should ensure that these new weapons are not against the protocols and approved by the protocol parties state. The benefit of this article is doubtful caused of what determines whether the weapon is a forbidden weapon or not is a country which has its own weapon and no sanction if the country concerned does not meet the requirement. $^{48}$

\section{Environmental Protection in ENMOD Convention}

Regulations about environmental protection in armed conflict beside of The Hague Conventions and Geneva Conventions, is the ENMOD Convention or Convention on the prohibition of military or any hostile use of environmental modification techniques. ${ }^{49}$ The problem of artificial modification of the environment for military warfare was brought to the international agenda in the early 1970s. In July

\footnotetext{
${ }^{47}$ Haryomataram, Op.Cit., p. 171

${ }^{48}$ Ibid., p. 174

${ }^{49}$ http://www.globalresearch.ca/environmentalmodification-techniques-enmod-and-climatechange/16413, accessed on 11 Oktober 2016, at 10:13 WIB
} 
1974, the United States and the Soviet Union agreed to hold bilateral talks on measures to address the dangers of using environmental modification techniques for military purposes and the next three rounds of discussions in 1974 and 1975. ${ }^{50}$ It became the background of ENMOD Convention. This Convention was adopted by UN General Assembly Resolution 31/72 of 10 December 1976 and signed in Geneva on 18 May 1977 and entered into force on 5 October 1978. The Convention consists of ten articles and the Annex. ${ }^{51}$

In the first article of ENMOD Convention there are several provisions in the regulation of environmental damage such as widespread, long-lasting, and terrible. ${ }^{52}$ Beside the provisions on environmental damage in Article I of ENMOD Convention, Article II of ENMOD Convention shall be governed by agreements between states that it shall not use environmental modification techniques for military or other similar purposes. ENMOD Convention's environmental modification technique is any technique through deliberate manipulation of natural processes to alter

\footnotetext{
${ }^{50}$ http://www.unog.ch/enmod, accessed on 11 Oktober 2016, at 13:06 WIB

${ }^{51}$ https://ihl-

data-

bases.icrc.org/ihl/INTRO/460?OpenDocument, accessed on 11 Oktober 2016, at 10:13 WIB

${ }^{52}$ Arlina Permatasari, Op.Cit., p. 260
}

the dynamics, composition or structure of the earth, including its biota, lithosphere, hydrosphere or space. ${ }^{53}$ This environmental modification technique once occurred in the world that was when the war that occurred between Vietnam and America and that war became the background of the establish of this convention.

The vietnam war has a large effect on environmental damage because during the vietnam war, the United States used a method of war called the "Environmental Modification Technique". ${ }^{54}$ That technique was used to modify the weather deliberately and resulting an excessive rainfall at the time, which in turn exacerbated the state of forests in Vietnam that had previously been bombed with highpowered ammunition (producing giant craters called craters). ${ }^{55}$ These action has damage to the environment by spreading Herbicides such as Agent Orange (containing harmful dioxin substances) by US troops to destroy rural trees leaving the toxic food chain and an estimated 4 million people affected by the disease, with

\footnotetext{
${ }^{53}$ Ibid., p. 261

54 https://www.britannica.com/event/VietnamWar, accessed on 11 Oktober 2016, at 10:32 WIB

${ }^{55}$ Triyana Yohanes and Hyronimus Rhiti, 2006 Research Report "Perlindungan Lingkungan Alam Melalui Ketentuan-Ketentuan Hukum Humaniter Internasional", p. 3.
} 
children born without limbs and other disabilities. $^{56}$

From that case it can be seen that environmental modifications can have devastating effects when used during the war. So it becomes the background of the establishment of ENMOD Convention. ENMOD Convention has been ratified by 77 countries and signed by 48 countries. $^{57}$ The role of the ENMOD Convention in environmental protection in armed conflict is to prevent the use of mass destructive weapons in the war. ${ }^{58}$ This is evidenced by the Sunshine project in 2000 , which examines ENMOD as a possible new tool for preventing the use of weapons of mass destruction, especially biological and toxin agents that aim for environmental protection and prevent the use of chemical technology and bilogy in the war. ${ }^{59}$

As mentioned earlier that the environment has become an important aspect of life so that various arrangements on environmental protection in armed con-

\footnotetext{
${ }^{56}$ http://www.history.com/topics/vietnamwar/vietnam-war-history, accessed on $11 \mathrm{Ok}$ tober 2016, at 10:28 WIB

${ }^{57}$ http://disarmament.un.org/treaties/t/enmod, accessed on 11 Oktober 2016, at 12:46 WIB

${ }^{58}$ Nessia Marga Letta, Analisis Pengaturan Internasional tentang "Prinsip Maksud Damai" dan bentuk Penerapannya Dalam Kegiatan Antariksa, "Jurnal Analisis dan Informasi Kedirgantaraan", Vol.9, No.1, 2012, p.77

${ }^{59}$ Ibid.
}

flict have been established. ${ }^{60}$ Beside Hague Law, Geneva Law, and the ENMOD Convention there are other regulations that governing about environmental protection in armed conflict, such as: ${ }^{61}$

1. St. Petersburg Declaration Renouncing the Use, in Time of War, of Explosive Projectiles under 400 Grammes in Weight, St. Petersburg, Nov. 29, 1868, AM. J. INT'L L. 1 (Supp.) 95;

2. Hague Convention (No. IV) Respecting the Laws and Customs of War on Land (1907), The Hague, Oct. 18, 1907, 36 Stat. 2277, TS No. 539;

3. Geneva Protocol for the Prohibition of the Use in War of Asphyxiating, Poisonous or other Gases and of Bacteriological Methods of Warfare (1925), Geneva, June 17, 1925, 26 UST 571, TIAS No. 8061, 14 ILM 49 (1975);

4. Convention Relative to the Protection of Civilian Persons in Time of War (Geneva, Aug. 12, 1949), 6 UST 3516, TIAS No. 3365, 75 UNTS 287 (Geneva Convention (IV)) and Additional Protocol I Relating to the Protection of Victims of International Armed Conflicts, June 8, 1977, 1125 UNTS 3, reprinted in 16 ILM 1391 (1977);

5. Treaty Banning Nuclear Weapon Tests in the Atmosphere, in Outer Space and Under Water (Moscow, Aug. 5, 1963), 480 UNTS 43 (1963) and Comprehensive Test Ban Treaty (Sept. 24, 1996);

6. Protocols II and III to the 1980 UN Convention on Certain Conventional Weapons, restricting mines and incendiary weapons;

7. Convention on the Prohibition of the Development, Production, Stockpiling and Use of Chemical Weapons and on

\footnotetext{
${ }^{60}$ Alexander Kiss and Dinah Ashelton, Op.Cit., p. 254

${ }^{61}$ Ibid., p. 255
} 
their Destruction, Paris, Jan. 13, 1993, 32 ILM 800 (1993).

Most of these regulations do not explicitly mention the environment, but they contain general principles and provisions that can be applied to promote environmental protection. This is because any action that is contrary to military objectives is against the law and endanger the environment. $^{62}$

\section{CONCLUSION}

Environmental protection in armed conflict according to international humanitarian law is governed by hague law and geneva law. In the hague law, environmental protection is governed by the convention IV of hague law and customs of war and land. Article 23 (g) which states the prohibition of the destruction of civilian objects in wars that affect the environment. In the geneva law, environmental protection is contained in Article 53 of Geneva Convention IV 1949 and Article 35 paragraph (3) and Article 55 paragraph (1) and (2) Additional Protocol I of 1977. Beside hague law and geneva laws, there are other arrangements to protect the environment in war that is contained in the ENMOD Convention which prohibits the use of environmental modification techniques as a means of warfare.

\footnotetext{
${ }^{62}$ Alexander Kiss and Dinah Ashelton, Loc.Cit.
}

\section{BIBLIOGRAPHY}

\section{Book}

Alexander Kiss and Dinah Ashelton, 2007. Guide to International Protection Law. Boston: Library of Congress Cataloging-in-Publication Data

Arnold, Robert. 2008. International Humanitarian Law dan Human Rights Law. Boston: Martinus Nijhoff Publisher

C. De Rover, 2000. To Serve and To Protect Acuan Universal Penegakan HAM. Jakarta: RajaGrafindo Persada

Djatikoesoemo. 1956. Hukum Internasional Bagian Perang, N.V. Jakarta:Pemandangan Djakarta

Haryomataram. 2005. Pengantar Hukum

Humaniter. Jakarta: Raja Grafindo

Nasution, Adnan Buyung, 2006. Instrumen Pokok Hak Asasi Manusia. Jakarta: Yayasan Obor Indonesia

Permanasari, Arlina. 1999. Pengantar Hukum Humaniter. Jakarta: Miamita Print

Rhiti, Hyronimus. 2006. Kompleksitas Permasalahan Lingkungan Hidup, Yogyakarta: Andy Offset,

Rurherford, Paul. ---------. Weapons of Mass Persuasion, Toronto: University of Toronto Press 
Siswanto, Arie. 2015. Hukum Pidana Internasional. Yogyakarta: Andi

Wardoyo, Broto. ----------. Perkembangan, Paradigma, dan Konsep Keamanan Internasional \& Relevansinya untuk Indonesia. Klaten: Nugra Media

Westing, Arthur H. 1988. Cultural Norm, War and the Environment. New York: Oxford University Press.

\section{Journals, Articles and Other Internet Resources}

F.Kalshoven, 1978, Reaffirmation and Development of International $\mathrm{Hu}-$ manitarian Law Applicable in Armed Conflicts : The DiplomaticConference", Geneva, 1974-1977 (PartII), Netherlands Yearbook of International Law, vol.9

Harry Purwanto, 2006, "Hukum Humaniter Internasional dan Hukum Hak Asasi Manusia”, Jurnal Mimbar Hukum, Vol. 18, No.2

Jean-Marie Henckaerts, 2005, Studi (kajian) tentang Hukum Humaniter Internasional Kebiasaan: Sebuah sumbangan bagi pemahaman dan penghormatan terhadap tertib hukum dalam konflik bersenjata, Jakarta, Vol. 87

Nessia Marga Letta, 2012, Analisis Pengaturan Internasional tentang "Prinsip Maksud Damai" dan ben- tuk Penerapannya Dalam Kegiatan Antariksa, "Journal Analisis dan Informasi Kedirgantaraan", Vol.9, No.1

Peter Richard \& Michael N.Schmitt, 1999, “Mars Meets Mother Nature: Protecting the Environment During Armed Conflict”, Stetson Law Review, Vol. 28

Triyana Yohanes dan Hyronimus Rhiti, 2006, Research Report "Perlindungan Lingkungan Alam Melalui Ketentuan-Ketentuan Hukum Humaniter Internasional"

http://disarmament.un.org/treaties/t/enmod , accessed on 11 Oktober 2016, at 12:46 WIB

http://indonesian.irib.ir/ranah/kultur/item/ 102680-antisipasi-perusakan lingkungan-hidup-akibat-perang, accessed on 10 Oktober 2016, at $14: 04$

http://www.accord.org.za/ajcr-

is-

sues/\%EF\%BF\%BCenvironmentalcauses-and impacts-of-thegenocide-in-rwanda/, accessed on 10 Oktober 2016, at 17:42 WIB https://www.britannica.com/event/Vietna $\mathrm{m}$-War, accessed on 11 Oktober 2016, at 10:32 WIB 
http://www.berpendidikan.com/2015/06/ar

ti-penting-lingkungan-hidup-

bagi.html, diakses 10 Oktober 2016 , at $14: 18$

http://www.globalissues.org/article/87/the

-democratic-republic-of-congo, diakses pada 10 Oktober 2016, at 17:31 WIB

http://www.globalresearch.ca/environment al-modification-techniques-enmodand climate-change/16413, accessed on 11 Oktober 2016, at 10:13 WIB

http://www.history.com/topics/vietnamwar/vietnam-war-history, accessed on 11 Oktober 2016, at 10:28 WIB

http://www.lenntech.com/environmentaleffects-war.htm, accessed on 10 Oktober 2016, at 17:35 WIB http://www.lenntech.com/environmentaleffects-war.htm, accessed on 10 Oktober 2016, at 17:35 WIB http://www.redcross.org.uk/Aboutus/Who-we-are/Museum-and archives/Historical-factsheets/TheBattle-of-Solferino, accessed on 22 september 2016, at 20:18

http://www.unog.ch/enmod, accessed on 11 Oktober 2016, at 13:06 WIB https://ihl-

databa-

ba-

ses.icrc.org/ihl/INTRO/460?OpenD ocument, diakses pada 11 Oktober 2016, at 10:13 WIB

http://www.worldlii.org/int/journals/ISIL

YBIHRL/2001/13.html, accessed on 10 Oktober 2016, at 20:39 WIB

https://www.britannica.com/event/Vietna m-War, accessed on 11 Oktober 2016, at 10:32 WIB

https://www.icrc.org/en/movement, accessed on 22 september 2016, at $20: 12$

https://www.icrc.org/eng/resources/docum ents/misc/additional-protocols 1977.htm, accessed on 10 September 2016, at 20:11 WIB

\section{Other Documents}

Convention on the prohibition of military or any hostile use of environmental modification techniques 1978 (ENMOD Convention)

The Hague Convention IV

Geneva Convention IV

Additional Protocol I

Statute of the International Court of Justice 